Andrews University

Digital Commons @ Andrews University

Faculty Publications

2011

\title{
CEO Demographics and Accounting Fraud: Who is More Likely to Rationalize Illegal Acts?
}

Carmelita J. Troy

Andrews University, troyc@andrews.edu

Ken G. Smith

University of Rhode Island

Madeline A. Domino

Georgia State University

Follow this and additional works at: https://digitalcommons.andrews.edu/pubs

Part of the Accounting Commons

\section{Recommended Citation}

Troy, Carmelita J.; Smith, Ken G.; and Domino, Madeline A., "CEO Demographics and Accounting Fraud: Who is More Likely to Rationalize Illegal Acts?" (2011). Faculty Publications. 1530.

https://digitalcommons.andrews.edu/pubs/1530

This Article is brought to you for free and open access by Digital Commons @ Andrews University. It has been accepted for inclusion in Faculty Publications by an authorized administrator of Digital Commons @ Andrews University. For more information, please contact repository@andrews.edu. 


\title{
CEO demographics and accounting fraud: Who is more likely to rationalize illegal acts?
}

Strategic Organization 9(4) 259-282

(C) The Author(s) 20II Reprints and permission: sagepub. co.uk/journalsPermissions.nav DOI: |0.1|77/|476|270||42|534 soq.sagepub.com

\section{Carmelita Troy}

Andrews University, USA

\section{Ken G. Smith}

University of Rhode Island, USA

\section{Madeline A. Domino}

Georgia State University, USA

\begin{abstract}
This article proposes that key CEO demographic factors reflect alternative modes of rationalizing the choice to engage in and/or facilitate accounting fraud. Specifically the authors theorize that younger, less functionally experienced CEOs and CEOs without business degrees will be more likely to rationalize accounting fraud as an acceptable decision. Based on a sample of 312 fraud-committing and control firms, the study finds support for the authors' predictions. It also finds that CEO stock options (a form of executive equity incentive) also predict fraud, and that this relationship is not moderated by CEO demographics. The study thus extends upper echelon theory by demonstrating how key demographic variables influence CEO decisions to rationalize accounting fraud.
\end{abstract}

\section{Keywords}

CEO demographics, financial statement fraud, fraud triangle, rationalization

\section{Introduction}

Accounting and financial statement fraud and chief executive officer (CEO) participation have long been documented. The Committee of Sponsoring Organizations of the Treadway Commission (COSO, 1999) report concluded that in 83 percent of fraud cases, going back to 1987, the CEO and/or CFO directed or was involved in the fraud. And since 1999, the involvement and indictment of CEOs in financial statement fraud have run rampant. Tyco lost US $\$ 100$ billion in market value (a sum that exceeds Enron's total loss) after it was disclosed that CEO Kozlowski had manipulated 
earnings. Prior to the disclosure, Kozlowski quietly sold US\$500 million worth of his own stock back to the company (Business Week, 2002). It has become increasingly common for convicted CEOs to receive stringent financial penalties and/or imprisonment for these crimes (New York Daily News, 2009). Enron's Jeff Skilling was sentenced to over 24 years' imprisonment as a result of his 2006 conviction. Bernard Madoff was sentenced to 150 years in prison by a federal judge (New York Times, 2009) joining the ranks of Richard Scrushy, Bernie Ebbers, John Rigas and others (New York Daily News, 2009; New York Times, 2007, 2009; Searcey and Yuan, 2005; Wall Street Journal, 2007).

The wealth of multidisciplinary research on financial statement fraud finds that industry and firm-level factors are predictors of fraud (Clinard and Yeager, 1980; Daboub et al., 1995; McKendall and Wagner, 1997; Merton, 1938; Pfeffer and Salancik, 1978; Sutherland, 1949; Zahra et al., 2005). Gross (1978) finds that it is the 'top people' in an organization who most often engage in illegal corporate activity. While these perspectives on fraud are important, there has also been a call to focus on a behavioral perspective of managerial elites to explain why well-intended and highly compensated managers may act in a particular way (Ashford and Anand, 2003; Nielson, 2009; Pettigrew, 1992). Prior research has associated top management team demographics with a variety of important firm outcomes including strategy, innovation and performance (Bantel and Jackson, 1989; Smith et al., 1994). A few management scholars advance the notion that key individual demographics (e.g. age, experience, gender, education) are important to predicting top management fraud (Greve et al., 2010; Hambrick, 2007a; Schrand and Zechman, 2010; Zahra et al., 2005, 2007). Boone and Hendricks (2009) argue that CEOs' preferences and knowledge account for a larger impact on firm outcomes than those of the top management team as a whole.

Zahra et al. $(2005,2007)$ theorize that individual characteristics of the CEO, such as charismatic leadership, age, experience level and MBA and military education moderate the rationalization to engage in fraud. Yet, beyond the Zhang et al. (2008) study of CEO compensation and earning manipulation, there has been little attempt to empirically study the connection between individual CEO characteristics and accounting fraud. The limited empirical research attention to CEO demographics that may predict fraud is surprising, given the prominent role of CEO strategy in the literature (Ashford and Anand, 2003; Hambrick and Mason, 1984; Nielson, 2009; Pettigrew, 1992) and society's outrage at this all-too-common phenomenon. The purpose of this article is to study the role of CEO demographics in accounting fraud which can contribute to improving both CEO selection and the governance structure designed to prevent these unlawful acts.

We draw from Zahra et al. (2005, 2007) and Hambrick (2007a) to theorize and empirically examine the extent to which individual CEO characteristics are associated with financial statement fraud. Hambrick (2007a) argues that because executives have limited information processing capabilities and bounded rationality, it is useful to study their individual demographic variables because they serve as filters for individual interpretation of situations and the choices they make. Since obtaining and measuring data on an executive's individual values and personality may not be possible, Hambrick (2007a) suggests the use of demographic characteristics as proxies for these constructs. Thus, variables such as an executive's age, experience and educational background may be viewed as a way to link an executive's strategic choice to accounting fraud.

Sociologist and criminologist Donald Cressey (1953) developed the fraud triangle to explain the conditions necessary for fraud to occur. The triangle suggests that for fraud to occur three elements must be present: opportunity, incentive/pressure (also referred to as motivation) and rationalization. The opportunity exists because of the CEO's unique position as the top executive of the organization. The CEO possesses proprietary information about the firm's financial 
position, knowledge of the weaknesses in governance structure and internal controls, and is in a position of power and influence to override existing controls and engage in or facilitate accounting fraud. In the context of the CEO and financial statement fraud, motivation exists when the company's financial reports affect the level of CEO financial compensation (Schrand and Zechman, 2010; Zhang et al., 2008).

In the presence of opportunity and motivation, a CEO will engage in fraud only if the act is rationalized to create the perception that financial statement fraud is justified. According to Anand et al. (2004) rationalizations are mental strategies that allow an individual to view normally unethical acts as justified. Rationalizations neutralize negative feelings associated with what would otherwise be viewed as deviant or unethical behavior. Without rationalization, cognitive dissonance would create a great deal of anxiety, which would force the individual to view themselves in an unfavorable light (Festinger, 1957). 'Rationalization is the least observable element of the Fraud Triangle because it is tied to the inner thoughts and emotions of the perpetrator. The cheater mentally redefines their deception into a morally defensible act' (Antenucci et al., 2010: 80). Thus rationalization facilitates wrongdoing as it 'allows for the possibility that individuals termed corrupt by societal standards may nonetheless see themselves as ethical within the context of their organization' (Anand et al., 2004: 10,11). Holding opportunity and incentives constant, we can partially explain rationalization by understanding demographics. That is, older, functionally experienced CEOs with business degrees should have more difficulty rationalizing accounting fraud than would younger, less functionally experienced CEOs without a business degree.

While upper echelon theory explicitly argues that an individual's values, preferences, interpretation and action will be affected by his or her demographic characteristics (Hambrick and Mason, 1984), there are a number of different arguments and empirical findings in the literature about how demographics affect the likelihood of wrongdoing. For example Zhang et al. (2008) argued that long-tenured CEOs would be motivated by economic gain but also be risk adverse, and Schrand and Zechman (2010) suggested that more educated CEOs would, as a result of overconfidence, be inclined to take risks. Because we cannot open the black box that may ultimately explain rationalization and why demographics predict CEO choices, we use existing arguments and empirical findings in the literature to generate our hypotheses about CEO demographics. One of the key aspects of upper echelon theory is that an individual's values, preferences, interpretation and actions will be affected by the context in which choices occur. Hambrick noted that 'executives act on the basis of their personalized interpretations of the strategic situations they face' (Hambrick, 2007a: 334). Understanding differences in senior executives' perceptions and interpretations is of great importance, in that a CEO is not merely reporting facts, but must interpret them in order to make key choices (Starbuck and Mezias, 1996). Individual interpretations among executives infer that their perceptions may be highly divergent.

Given that CEOs' values, preferences and personalized interpretations work in conjunction with situational factors, we theorize that the relationship between CEO rationalization, as evidenced by demographics, and the likelihood of accounting fraud will be moderated by one form of equity incentives - CEO stock options. Prior research has established an association of high levels of CEO stock options with higher levels of financial statement fraud (Zhang et al., 2008). Higher levels of stock options will increase the financial motivation and rationalization of accounting fraud, for younger, less functionally experienced CEOs and CEOs without a business degree.

Our results provide new insights as to the role of the individual CEO differences which predict financial statement fraud as well as a glimpse into how these relationships are moderated by 
financial incentives. This is important because we know that choices are also affected by situational factors but these factors have not been clearly delineated (Hambrick, 2007a). Furthermore, our theory on the role of stock options as a moderator can enhance the research that has found direct effects for stock options and accounting fraud by identifying another explanation by which stock options influence accounting fraud (Zhang et al., 2008).

\section{Financial statement fraud}

Financial statement fraud research has typically been explained as a deliberate rational choice to circumvent accounting rules and regulations for personal gain, which results in financial reports that are misleading or deceptive (Siegel, 1992). This fraud entails violating generally accepted accounting principles (GAAP), through the overstatement of revenues, understatement of expenses, or overstatement of assets (Beasley et al., 2000; COSO, 1999; Dechow et al., 1996; Feroz et al., 1991). Sutherland (1949) suggests that criminal behavior increases as it is associated with favorable outcomes. Financial statement fraud has been motivated by the financial condition of the firm, its resources or lack of resources (COSO, 1999), by the desire to meet analysts' earnings targets (Dechow et al., 2003), or by poor corporate performance. The extant literature in finance finds a significant relationship between poor corporate performance and CEO dismissal (Ertugrul and Krishnan, 2010; Kang and Shivdasani, 1997). The research on accounting fraud has examined the role of governance, executive compensation, the quality of accounting information, audits and auditors, fraud risk assessments and earnings management (Beasley, 1996; Burns and Kedia, 2008; Carcello and Nagy, 2004a, 2004b; Cheng and Farber, 2008; Dechow et al., 1996; Erickson et al., 2006; Jia et al., 2009; Jones et al., 2008; Laux and Laux, 2009; Prawitt et al., 2009 Uzun et al., 2004).

Research also suggests that even if not directly involved, a CEO may direct or enable others in committing financial statement fraud (Ermann and Lundman, 1987), an argument also advanced by Zahra et al. $(2005,2007)$. To that end, the CEO may decide to adopt a passive and/or permissive stance toward unethical conduct of subordinates, by looking 'the other way' (Daboub et al., 1995; Kriesberg, 1976). When illegal activities come to light, top managers may 'arrange patterns of reporting so that they cannot find out (or at least, if they find out, they find out in such a way that it can never be proved)' (Stone, 1975: 53).

Thus, and consistent with fraud triangle, we theorize that a CEO has the opportunity to commit accounting fraud because of his or her position and knowledge at the top of the organization and has the motivation because of perceived personal and organization benefits. Ultimately, however, CEOs must rationalize the fraud as an acceptable course of action. This rationalization process might include CEO beliefs that 'I can't fail my employees and stockholders', 'I know we can make this up next quarter', 'just this once', or perhaps a belief that 'everybody does it'. The extent to which rational choice is influenced by the demographics of those bearing the risks and who are ultimately responsible, is of importance, since the consequences of detected accounting fraud can be severe.

\section{Hypothesis development}

In the widely cited upper echelon theory, Hambrick and Mason (1984) contend that top-level strategic choices are a function of managers' values and cognitions. Hambrick (2007a) specifically proposes that an individual's values, preferences, interpretation and actions will be affected by his or her demographic characteristics. Social psychology literature explains values and cognitions as 
reflections of an individual's knowledge, together with attributions and the relationship among those attributes (Fiske and Taylor, 1991). Prior experience and knowledge build hierarchically arranged categories to organize an individual's knowledge about the world. Categories are connected hierarchically from the simplest to the more complex levels of abstraction. Importantly, this explains differences in what people know, how they reason, and how they use their knowledge in a given situation. Just as Hambrick and Mason (1984) suggest that heterogeneous top management teams will bring diverse knowledge skills to a situation, we suggest that diverse executive knowledge categories will bring a greater variety of knowledge to the situation.

Our hypotheses focus on three CEO demographics - age, functional experience and education. Variation among CEOs in these demographic areas reflects disparity in the structure of individual knowledge. Specifically, older CEOs are expected to have a greater amount of knowledge and a wider range of different types of knowledge about themselves and the world in which they live. Further, CEOs with a diverse set of functional experiences within the firm will have broader and deeper sets of hierarchical categories than a CEO with less functional experience. In addition, education can represent differences in knowledge categories (Fong et al., 1986), such that CEOs with business degrees may attain and retain more knowledge about accounting and business law than managers without such education. Finally, we theorize that how a CEO rationalizes accounting fraud will be moderated by financial incentives, as incentives will affect the level of motivation.

\section{Executive age}

Executive age has been empirically connected to cognitive development and awareness (Daboub et al., 1995). Researchers found negative relationships between age and Machiavellian behaviors (Hunt and Chonko, 1984) and unethical behaviors (Kelley et al., 1990). Age impacts strategy (Hambrick and Mason, 1984) due in part to the impact of life experiences (Ireland et al., 1987). Shuman and Scott (1989) concluded that the events experienced during youth were important to attitudes developed in later years.

Hambrick and Mason (1984) proposed that younger executives undertake riskier strategies, perhaps alluding to the 'follies of youth'. In support, Markóczy (1997) found that younger managers are greater risk-takers, and Brouthers et al. $(2000$ : 867, 876) reported that younger managers are more 'strategically aggressive' than older managers, especially during times of turbulence. In a study of white-collar crime, Price and Norris (2009) reported that younger managers are more vulnerable to societal and organizational pressures. In contrast, Hambrick and Mason (1984) contend that older executives are more conservative, possibly because they are better able to judge risks and negative consequences. Older managers are less likely to challenge the rules within an organization (Child, 1974). Kelley et al. (1990) assert that maturity is associated with higher levels of moral development and older employees have stricter interpretations of their firm's ethical standards of conduct (Serwinek, 1992). Older executives are less likely to yield to industry and organizational pressures (Daboub et al., 1995) and according to Price and Norris (2009) greater age serves as a protective factor against these pressures.

The risk encountered with accounting fraud is that it will be discovered. The repercussions of getting caught committing or facilitating financial statement fraud can be devastating. Even when the Securities and Exchange Commission (SEC) does not impose sanctions on the individuals in the firm responsible for these acts, there are individual reputational costs that the market imposes on the individuals who are associated with these crimes. As a consequence of the broad set of experiences and maturity that comes with age, an older CEO is more likely to view the results of rationalizing financial statement fraud as being too costly. 
Following Reynolds (2006), we theorize that older executives will have acquired a more developed knowledge base to make choices than will younger CEOs and that with age there will be more structure, leading to more efficiency and accuracy (Fiske and Taylor, 1991). As such, an older executive will have a more difficult time rationalizing accounting fraud than will a younger executive. Following this logic, we predict:

Нyротнesis 1: Younger CEOs are more likely to engage in or facilitate accounting fraud.

\section{Executive functional experience}

Functional background has been utilized as a knowledge-based individual difference in prior research (Boone and Hendricks, 2009) and it has been linked to variation in CEO strategic choices (Hambrick and Mason, 1984; Herrmann, 2002) as well as executive management's perceptions and interpretations of problems (Starbuck and Mezias, 1996). Variations in functional experience reflect a range of knowledge categories that a CEO uses to rationalize choices. A more diverse range of categories allows the CEO to draw upon more and different types of information. CEOs with a greater breadth of functional experience should exhibit greater self-regulation abilities and more refined cognitive processing (Glaser, 1984). Furthermore, with knowledge organized into a broader set of categories and these categories connected in complex and hierarchical patterns, functionally experienced CEOs will have a greater amount and variety of knowledge to draw upon. Child (1974) claimed less experienced managers may lack knowledge of key principles to guide choices, unable to consider as many alternatives since they have a smaller range of knowledge categories to draw upon. Because of a narrower set of knowledge categories they will have limited information processing capabilities compared to those CEOs with diverse functional experience. This naiveté or illusion of control, favorability, or optimism (Messick and Bazerman, 1996) may mean that less experienced CEOs will more easily rationalize accounting fraud.

Finkelstein and Hambrick (1996) suggest that functional experience reflects an executive's breadth of knowledge. Functional specialization results in executives approaching problems from the perspective(s) that is (are) common to that particular function (Gupta, 1984). Herrmann (2002) suggests that the greater the number of various perspectives and functional experiences that the executive has been exposed to, the broader base of alternatives and solutions the CEO can consider. Those executives who have greater exposure to different functions in their organization will have a greater opportunity to learn and develop their knowledge base as it relates to their particular company and its customers, markets, financing and so on. Thus, breadth of functional experience should be accompanied by a wider range of knowledge categories with executives who have more functional experience less likely to rationalize accounting fraud (Hambrick and Mason, 1984; Zhang et al., 2008). Thus, we hypothesize:

Hypothesis 2: CEOs with fewer in-firm functional experiences are more likely to engage in or facilitate accounting fraud.

\section{Executive business education}

Chief executive officers are generally well educated, with most having completed college (Chandy, 1991; Palia, 2000). According to cognitive theory, education is positively related to cognitive abilities (Finkelstein and Hambrick, 1996) and more highly educated executives are better able to generate novel and creative solutions to various problems (Bantel and Jackson, 1989). Hambrick and Mason (1984) suggest that education can influence strategic choices within organizations. 
Higher levels of CEO education are associated with greater innovation (Grimm and Smith, 1991) and advanced ability to process and integrate information (Wiersema and Bantel, 1992). The level of education has also been shown to have a positive relationship to the level of moral development (Freeman and Gilbert, 1988; Rest and Thoma, 1985). Research in social cognition supports the notion that education improves decision-making (Fisk and Taylor, 1991; Fong et al., 1986; Lehman et al., 1988).

Business education also impacts executive rationalization. Daboub et al. (1995) theorized that graduate business education is associated with greater self-interested behavior and they predict that executives with MBAs would be more likely to be involved in corporate illegal activity. Critics of business education suggest that the focus of the curriculum is directed at increasing profits at the expense of teaching ethics and values (Gioia, 2002; Gioia and Corley, 2002; Pfeffer and Fong 2004). An Aspen Institute study (2001) suggested that a business school education actually weakened the moral character of these graduates. Gioia (2002) attributes the crisis in corporate confidence to the focus on hard business courses, such as accounting, finance, and not injecting ethics and values into the curriculums.

Conversely, Barker and Mueller (2002) report that the analytic skills which are taught in business schools tend to be geared toward avoiding big mistakes or losses. This conservative outlook may evoke a more rational and systematic approach to business choices, that is, education in business may help to develop skills that are used to distinguish between good strategic choices with acceptable payoffs and actions that are potentially costly mistakes. Business education not only engenders improved ability to integrate and analyze information, but it may also train managers to reject those actions and behaviors that are associated with negative consequences.

Business education, when there is a focus on profits at any cost, may lead to greater likelihood of rationalizing accounting fraud. But the preponderance of literature indicates that higher education in general is associated with more refined decision-making. Given this dichotomy, we postulate that CEOs schooled in business administration will be more aware of the fundamentals of accounting, including the related subjects of business processes and internal controls, the monitoring role of the board of directors and the potential repercussions and penalties of unethical behavior. Thus we assert that CEOs with a business education will be less likely to rationalize accounting fraud:

Нypothesis 3: CEOs who have earned a business degree are less likely to engage in or facilitate accounting fraud.

\section{The moderating effects of CEO stock options on the relationship between CEO demographics and accounting fraud}

Hambrick's (2007a) upper echelon framework calls for more study on the interactive effects of executive demographics with context situations such as executive equity incentives. For example, he notes: 'Research in the upper echelons vein indicates that executive characteristics influence strategic outcomes. A separate body of literature demonstrates that executive rewards systems affect company behaviors' (Hambrick, 2007a: 339). The extant research that examines executive demographics and compensation in tandem (Hambrick, 2007a) is minimal. Given that a large part of a CEO's compensation is equity based, we study the impact of CEO stock options, which have been empirically linked to accounting fraud (Zhang et al., 2008), on the relationship between CEO demographics and the likelihood of accounting fraud. We argue that stock options will affect the level of CEO motivation. 


\section{Executive stock options}

The pay packages of today's executives generally include a significant component of stock options that increase in value as goals, earnings or growth targets, or stock-price targets are met (Hall and Murphy, 2002). DeFusco et al. (1990) and Brockman et al. (2010) found that executives that hold stock options undertake more risky opportunities. The agency literature posits that incentives are a way to align the agent's and the firm's interests (Jensen, 2001; Tosi et al., 2000), but Uzun et al. (2004) and Zhang et al. (2008) also report that 'lucrative' stock options play a role in corporate malfeasance.

A broad swath of research on executive stock options concludes that $\mathrm{CEO}$ stock options provide incentives for fraudulent acts by executives (Beasley et al., 2001; Jensen, 2001; O'Connor et al., 2006 Tosi et al., 2000; Uzun et al., 2004). Given the significant amount of research on the stock option-fraud relationship, we study the extent to which the relationship between CEOs' stock options will attenuate the CEO demographics-fraud relationship. Specifically, following the logic of the first three hypotheses, we theorize that CEOs with a more complex and developed knowledge base measured as older, functionally experienced and business educated CEOs would be less influenced by the presence of high levels of stock options.

We have asserted that an older CEO will have multifaceted knowledge categories and have developed a more hierarchical knowledge base to draw from than will a younger CEO. Because of this we suggest that an older CEO would be less likely to rationalize accounting fraud than younger CEOs. Older CEOs, with complex, developed and perhaps better knowledge of the business world should be better able to understand and manage the pressures that accompany stock option incentives. In other words, given the same level of stock options, older CEOs would be less likely to rationalize accounting fraud than would younger CEOs. In essence, with more knowledge to draw upon, these CEOs would be more aware of and understand the ways that stock options can lead to unacceptable rationalization. Younger CEOs may be more aggressive in order to enhance their wealth (Brouthers et al., 2000; MacCrimmon and Wehrung, 1990) and more likely to rationalize as a normal part of business. Therefore, we expect that younger managers will be more likely to succumb to the pressures and be motivated by the financial gain of stock options than will older managers.

As noted, CEOs with broad functional experience will have a wider set of knowledge categories to draw upon, to discern the impact of a choice on the firm and the firm's functional segments. As Fiske and Taylor (1991) note, life experiences, both negative and positive, influence the complexity, accessibility and content of choices. As in the case of age, a CEO with a broad set of functional experiences and knowledge should be better able to realize and manage the pressures associated with stock options as compared to a CEO with a narrow range of experiences. With more functional experience, CEOs will be more confident in their actions (Child, 1974) and they will sense negative business events as less intimidating (Dunn, 2004).

Finally, a CEO with a business education should be more aware of and more capable of managing the influence of stock options toward the commitment of accounting fraud than CEOs without such education. CEOs with a business degree would be more likely to realize the longterm positive potential of stock options in building real corporate wealth and be less compelled by demands for short-term performance gains (e.g. Slater and Dixon-Fowler, 2010). CEOs without a business degree may not realize or know the importance of building real long-term corporate wealth in the same way as CEOs with a business degree. Given the same level of stock options, business-educated CEOs will be less likely to rationalize accounting fraud as acceptable. Thus we hypothesize: 
Hypothesis 4: The relationship between CEO demographics and the likelihood of accounting fraud will be moderated by the level of stock options, such that older, more functionally experienced CEOs who hold a business degree will be less influenced by high levels of stock options than will younger, less functionally experienced CEOs who do not hold a business degree.

\section{Methodology}

\section{Sample selection}

The sample of fraud firms was taken from the SEC Accounting and Auditing Enforcement Releases (AAERs) for violating the financial reporting requirements of the Securities and Exchange Act of 1934. This Act requires publicly traded firms to file financial reports with the SEC that must be in compliance with GAAP (see Dechow et al., 1996). Using AAERs as our source of sample firms provides us with a sample of firms that purposefully engaged in accounting violations (Beasley, 1996; Dechow et al., 1996). To identify the firms in our fraud sample, we analyzed the SEC enforcement actions issued from 1992 to 2005. Because of a change in compensation disclosure rules by the SEC, many companies, though not all, began disclosing standardized and detailed compensation data in 1992 (Stone, 1992). A firm was included in the sample if the necessary proxy and financial statement data were available for the fiscal year prior to the year the SEC enforcement action indicated the fraud started. As a result, we have 156 fraud firms in our sample where the fraud started between 1992 and 2004, there was either a guilty verdict in a criminal case or consent to the order or judgment imposed by the SEC, and for which there were complete data available.

Following prior research (see, for example, Beasley, 1996; Carcello and Nagy, 2004a, 2004b; Dechow et al., 1996; Kaminski et al., 2004; Uzun et al., 2004), a central part of our research design was to identify a control firm, not subject to SEC enforcement action, for each violator in the sample that closely resembled the fraud firm in terms of industry and size. In order to maximize the likelihood of using uncontaminated or clean data we selected the company in the industry that was closest in size based on total assets, using data from the year prior to the start of the fraud, to the fraud firm, based on the three- or four-digit SIC industry code (Beasley, 1996; Carcello and Nagy, 2004a, 2004b; Dechow et al., 1996; Uzun et al., 2004). To minimize the possibility that the control firm was not also engaging in or suspected of accounting irregularities, we conducted a search of press articles on Lexis-Nexis and the Business and Company Resource Center for reports of alleged unacceptable accounting practices in the sample of control firms. We found no reports of alleged accounting malfeasance for the companies in the final sample of control firms.

The entire sample consists of 312 publicly traded companies. Half or 156 of the firms, i.e. the fraud firms, were subject to SEC enforcement action and the other half were a sample of control firms. The firms studied come from 43 different industries, as measured by two-digit SIC codes, and therefore represent a broad cross-section of the business environment.

\section{Data sources}

All data were collected from the following publicly available sources: (1) Compustat; (2) SEC filings, including company DEF-14A (proxy statements) and company 10-K reports; (3) Dun and Bradstreet Reference Book of Corporate Managements; and (4) the Center for Research and Security Prices (CRSP) database. 


\section{Description of variables}

Dependent variable. In our outcome equation the dependent variable is accounting fraud and measured as a 1-0 dichotomous variable with 1 indicating that the firm was subject to SEC enforcement action for accounting violations and 0 indicating that the firm was in the sample of control firms.

Independent variables. CEO age is measured at the beginning of the year the fraud started, as reported in company DEF-14A (proxy) statements, company $10-\mathrm{K}$ reports and from the LexisNexis Academic Biographical Directories. CEO former functional positions is the number of functional/executive positions that the CEO held in the firm prior to becoming the CEO. Data on the number of CEO functional positions were collected from company DEF-14A (proxy) statements, company $10-\mathrm{K}$ reports and from the Lexis-Nexis Academic Biographical Directories. CEO business degree is a 1-0 dichotomous variable, equal to 1 if the CEO has an undergraduate or graduate degree in business and 0 , otherwise. This information was gathered from company DEF14A (proxy) statements, company 10-K reports and from the Lexis-Nexis AcademicBiographical Directories. CEO stock options is measured as the total value of the CEO's unexercised options divided by total compensation, all data taken from the year prior to the start of the fraud. When the fraud began in the CEO's first year, we used options and compensation data from that year. CEO stock options data were collected from company proxy statements.

Control variables. Following prior research we include measures of governance, industry, year, financial condition and firm size as control variables. These controls are added in order to address problems related to the potential threat of alternative explanations. Our governance variables are CEO stock ownership, CEO duality, board size and number of outside directors. Stock ownership as Morck et al. (1990: 32) proposed, 'may be the most effective deterrent to investments that dissipate market value'. This variable is computed as the percentage of outstanding company stock beneficially owned by the CEO divided by the number of shares outstanding for the company (Cheng and Warfield, 2005). Duality is a 1-0 variable, with 1 indicating that in the year the fraud began, the CEO was also chairman of the board, and 0, otherwise. Board size and outside directors are measured as the total number of directors and the number of non-employee directors, respectively, on the company's board of directors. Data for these governance variables were gathered from company proxy statements.

To control for potential underlying industry effects resulting from industry-specific considerations (Erickson et al., 2006), including the possibility that the SEC may at times spotlight a particular industry to investigate, each firm was classified according to industry. Similarly to Ning et al. (2007) we based our classification on the following industry categories: construction (SIC 15-17); manufacturing (SIC 20-39); transportation, communication and energy (SIC 40-49); wholesale and retail trade (SIC 50-59); finance, insurance and real estate (SIC 60-67); services (SIC 70-89); and other industries (SICs 01-14 and 90-99). We also control for the time period using dummy variables for the year the fraud began, as reported by the SEC.

'Fraudulent financial reporting has traditionally been associated with companies experiencing financial difficulties' (Report of the National Commission on Fraudulent Financial Reporting, 1987: 159). We use Altman's (1968) Z-score (a measure of financial distress), return on assets (ROA) and book-to-market value to measure and control for firm financial condition. Return on assets is measured as operating income scaled by average total assets. Book-to-market value, an indicator of firm value, is measured as the book value of company equity divided by market capitalization. Lastly, firm size is measured as the natural log of total assets (Carcello and Nagy, 2004a, 
2004b). Z-score, ROA, book-to-market value and firm size data were collected from Compustat at the balance sheet date for the year prior to the start of the accounting fraud.

\section{Heckman correction and research model}

Of interest in this research is the relationship between CEO incentives and accounting fraud. To test our hypotheses we use a Heckman two-step procedure ${ }^{1}$ to correct for possible selection bias related to incentives, particularly stock options granted to and held by the CEO. In the first step, the selection equation, we followed Lee (1983) and Smits (2003) and employed a logistic regression to estimate predicted values of the model. These predicted values are then used to calculate lambda, also known as the inverse Mills ratio or correction factor (Bascle, 2008). In the selection equation the dependent variable is a dummy variable set to 1 if the CEO is reported to have unexercised stock options, 0 otherwise. As is necessary, this indicator variable is not correlated with accounting fraud, but is correlated with our measure of CEO stock options. The second step, referred to as the outcome equation (Bascle, 2008) is our regression of interest. In the outcome equation a probit regression model is used to test the relation between the independent variables, defined below, and dependent variable: the occurrences of accounting fraud. A probit regression is a useful model for our substantial analysis because of the dichotomous nature of the dependent variable, accounting fraud. In addition to the independent and control variables that are included in the selection (first) equation, the outcome equation contains two additional variables, CEO stock options and the lambda, determined from the first equation. 'The coefficient of $\lambda$ indicates whether there is selection bias and what the direction of this bias is' (Smits, 2003: 9).

\section{Results}

Table 1 shows descriptive statistics and correlations for all variables. Table 2 reports the results of the probit regression analysis with Heckman's correction. The main effects model provides good explanatory power for accounting fraud $\left(\chi^{2}=337.832 ; p=.010\right)$. The coefficient for lambda is positive, but not significant, implying that selection bias is not empirically relevant.

Hypotheses 1, 2 and 3 address the relationship between the CEO demographic variables of age, in-firm functional experience and business education with accounting fraud. We expected to find that younger CEOs, CEOs with fewer functional positions in the company prior to becoming the firm's top executive and CEOs who did not have a business degree would be associated with greater likelihood of financial statement fraud. As expected, the coefficients of these demographic variables are negative and significant. Thus our hypotheses 1,2 and 3 are supported. The CEOs of the fraud firms were more likely, on average, to be younger $(\beta=-.027 ; p<.01)$, have fewer functional experiences within the company $(\beta=-.329 ; p<.001)$ and less likely to have a business degree $(\beta=-.573 ; p=.001)$.

The CEOs of the violator firms were, on average about 2.3 years younger than the CEOs of the control firms, a statistically significant difference $(t$-test $=-2.435 ; p<.05)$. The CEOs of the fraud firms also held significantly fewer function positions in the firm prior to becoming CEO than did the CEOs of the control firms. On average the CEOs of the fraud firms had held on average 1.46 functional positions in the firm prior to becoming CEO, while the CEOs of the control firms held nearly two (1.94) functional positions in the company, a significant difference $(t$-test $=-3.923$; $p<.001)$. The CEOs of the fraud firms were also significantly less likely to have a business degree. Forty of the fraud firms (25.6 percent) had CEOs who had a business degree, while 65 of the control firms (41.7 percent) had CEOs with a business degree $\left(\chi^{2}=8.972 ; p<.01\right)$. 
Table I. Descriptive statistics and correlations matrix

\begin{tabular}{|c|c|c|c|c|c|c|c|c|c|c|c|c|c|c|}
\hline & Mean & SD & I & 2 & 3 & 4 & 5 & 6 & 7 & 8 & 9 & 10 & 11 & 12 \\
\hline I Fraud & .50 & .50 & 1.00 & & & & & & & & & & & \\
\hline 2 CEO age & 52.17 & 8.93 & $-.13^{*}$ & 1.00 & & & & & & & & & & \\
\hline $\begin{array}{l}3 \text { CEO } \\
\text { experience }\end{array}$ & 1.70 & 1.39 & $-.18 * *$ & $*-.05$ & 1.00 & & & & & & & & & \\
\hline $\begin{array}{l}4 \text { CEO business } \\
\text { degree }\end{array}$ & .34 & .47 & $-.17^{* *}$ & $*-.08$ & $.17^{* *}$ & $* 1.00$ & & & & & & & & \\
\hline $\begin{array}{l}5 \text { CEO stock } \\
\text { options }\end{array}$ & 6.43 & 15.33 & $3.13 *$ & -.01 & $.21^{* *}$ & $* .04$ & 1.00 & & & & & & & \\
\hline $\begin{array}{l}6 \text { CEO stock } \\
\text { ownership }\end{array}$ & .10 & .14 & -.04 & .06 & $-.16^{* *}$ & $*-.06$ & $-.13^{*}$ & 1.00 & & & & & & \\
\hline 7 Duality & .65 & .48 & -.01 & $.18^{* *}$ & -.11 & .04 & .07 & $.20^{* * *}$ & 1.00 & & & & & \\
\hline 8 Indus SIC I5-17 & .02 & .14 & .00 & $.16 * *$ & .03 & .00 & -.05 & .09 & .05 & 1.00 & & & & \\
\hline 9 Indus SIC 20-39 & 9.41 & .49 & -.01 & $.19 * *$ & -.02 & -.05 & .03 & -.04 & .02 & $-.12^{*}$ & 1.00 & & & \\
\hline 10 Indus SIC $40-49$ & $9 \quad .06$ & .23 & .00 & .07 & .00 & -.06 & -.02 & -.05 & .04 & -.04 & $-.21 * *$ & 1.00 & & \\
\hline II Indus SIC 50-5I & I .07 & .26 & .00 & -.07 & .00 & .02 & -.08 & -.04 & $-.14 *$ & -.04 & $-.23 * *$ & -.07 & 1.00 & \\
\hline 12 Indus SIC 52-59 & 9.10 & .30 & .00 & -.04 & .01 & -.05 & -.03 & .03 & .03 & -.05 & $-.27 * *$ & -.08 & -.09 & 1.00 \\
\hline 13 Indus SIC 60-67 & $\begin{array}{ll}7 & .01 \\
\end{array}$ & .II & .00 & .07 & $-.12^{*}$ & -.08 & -.04 & -.02 & .02 & -.02 & -.10 & -.03 & -.03 & -.04 \\
\hline 14 Indus SIC 70-88 & $8 \quad .29$ & .46 & .00 & $-.23 * *$ & .05 & $.15^{* *}$ & * .08 & -.02 & .00 & -.09 & $-.54 * *$ & $-.16^{* *}$ & $*-.18^{* *}$ & $-.21 * *$ \\
\hline $15 \quad 1992$ & .08 & .28 & .00 & -.02 & $-.29 * *$ & $*-.12 *$ & -.10 & -.02 & -.02 & -.04 & $-.11 *$ & .03 & .01 & $.22 * *$ \\
\hline 161993 & .08 & .28 & .00 & -.02 & $-.21^{* *}$ & $*-.09$ & -.09 & .00 & .05 & -.04 & .08 & -.08 & -.08 & -.02 \\
\hline $17 \quad 1994$ & .04 & .19 & .00 & -.03 & $-.16 * *$ & $*-.11$ & -.04 & $.15 * *$ & .01 & -.03 & -.03 & -.05 & -.06 & $.16 * *$ \\
\hline 181995 & .03 & .18 & .00 & -.02 & $-.16 * *$ & ${ }^{*}-.09$ & -.05 & .03 & -.02 & -.03 & -.01 & -.05 & -.05 & -.06 \\
\hline 191996 & .07 & .26 & .00 & $.22^{* *}$ & $-.16^{* *}$ & $*-.04$ & -.06 & .03 & -.01 & $.14^{*}$ & $.18 * *$ & -.07 & .02 & -.09 \\
\hline 201997 & .03 & .18 & .00 & .00 & $-.18^{* *}$ & ${ }^{*}-.01$ & -.05 & -.04 & .02 & -.03 & $.14 *$ & -.05 & .09 & -.06 \\
\hline 211998 & .17 & .37 & .00 & -.02 & $.14 *$ & .05 & .00 & -.06 & .02 & .06 & -.06 & $.18 * *$ & ${ }^{k} .01$ & -.03 \\
\hline $22 \quad 1999$ & .19 & .40 & .00 & $-.14 *$ & $.22 * *$ & * . .08 & $.18^{* *}$ & $=.01$ & .03 & -.07 & -.01 & -.05 & -.07 & -.05 \\
\hline 232000 & .14 & .35 & .01 & .03 & $.26 * *$ & $* .06$ & .11 & -.03 & .01 & .08 & .06 & .06 & -.04 & -.01 \\
\hline 242001 & .09 & .29 & .00 & .01 & $.13^{*}$ & $.13^{*}$ & -.02 & -.05 & -.10 & -.04 & $-.22^{* *}$ & .02 & $.26 * *$ & -.03 \\
\hline 252002 & .05 & .21 & -.02 & .05 & -.03 & -.03 & -.05 & .06 & .01 & -.03 & .02 & -.06 & -.06 & .03 \\
\hline $26 Z$ score & 1.28 & 1.40 & -.05 & .06 & .01 & .02 & -.07 & .02 & .01 & .00 & .00 & -.05 & $.24 * *$ & $.16 * *$ \\
\hline $27 \mathrm{ROA}$ & -.01 & .41 & .08 & .06 & .05 & -.02 & .09 & .01 & .09 & .02 & -.06 & .03 & .05 & .04 \\
\hline 28 Book-to-market & t. .57 & (1) & -.05 & $.12^{*}$ & -.09 & -.09 & $-.21^{* *}$ & $.21^{* *}$ & -.05 & .08 & -.08 & .01 & .07 & -.04 \\
\hline $29 \mathrm{LN}$ total assets & 4.90 & 2.22 & .05 & $.11 *$ & $.23 * *$ & * .04 & $.23^{* *}$ & $-.29 * *$ & $.15^{* *}$ & -.01 & -.09 & $.18^{* *}$ & ${ }^{k} .01$ & $.14^{*}$ \\
\hline 30 Board size & 7.26 & 2.80 & -.04 & $.19 * *$ & $.12 *$ & .07 & .09 & $-.28^{* * *}$ & .02 & -.01 & .00 & $.18 * *$ & .02 & .08 \\
\hline $\begin{array}{l}\text { 31 Outside } \\
\text { directors }\end{array}$ & 4.49 & 2.62 & $-.11 *$ & .09 & $.21^{* * *}$ & * $\quad .06$ & $.15^{* *}$ & $-.33^{* *}$ & .01 & -.03 & -.02 & $.18^{* *}$ & k .05 & .05 \\
\hline
\end{tabular}




\begin{tabular}{llllllllllllllllll}
\hline 13 & 14 & 15 & 16 & 17 & 18 & 19 & 20 & 21 & 22 & 23 & 24 & 25 & 26 & 27 & 28 & 29 & 30
\end{tabular}

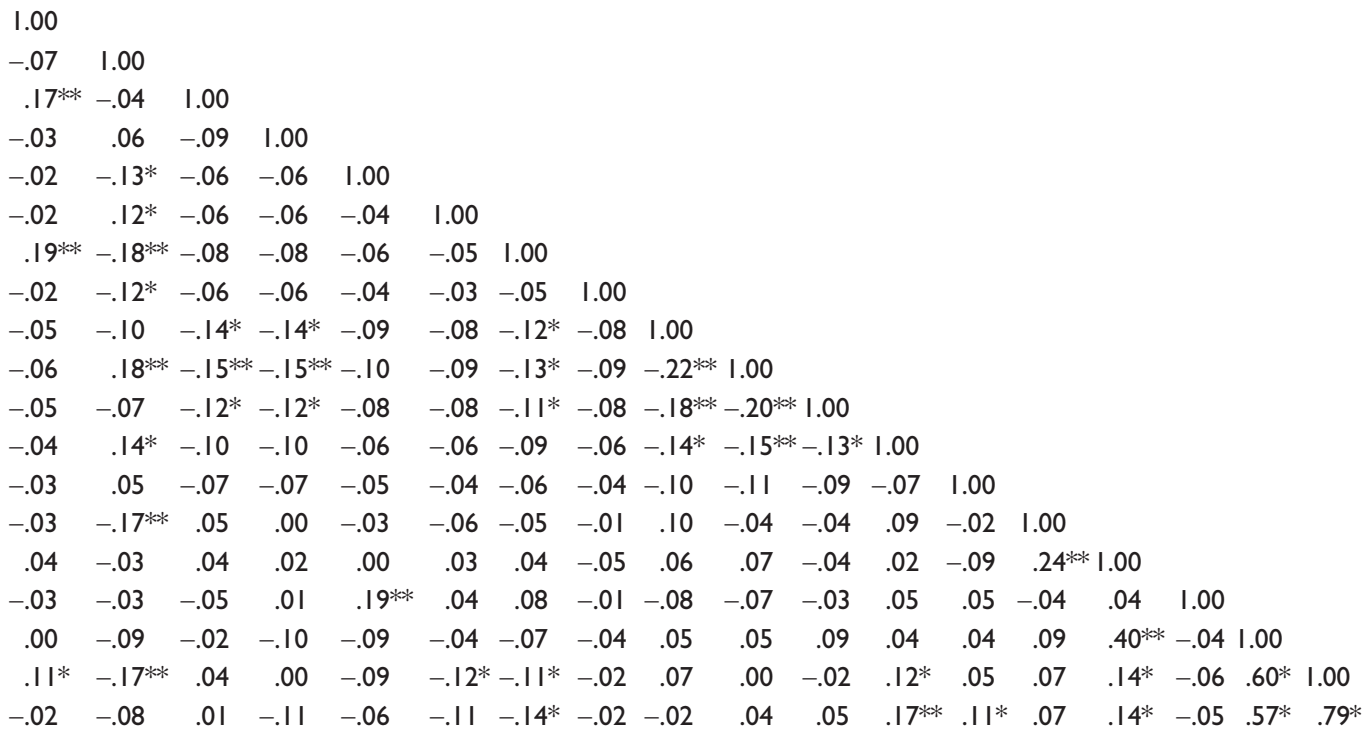

$N=3 \mid 2$.

$* p<.05,{ }^{* *} p<.01$. 


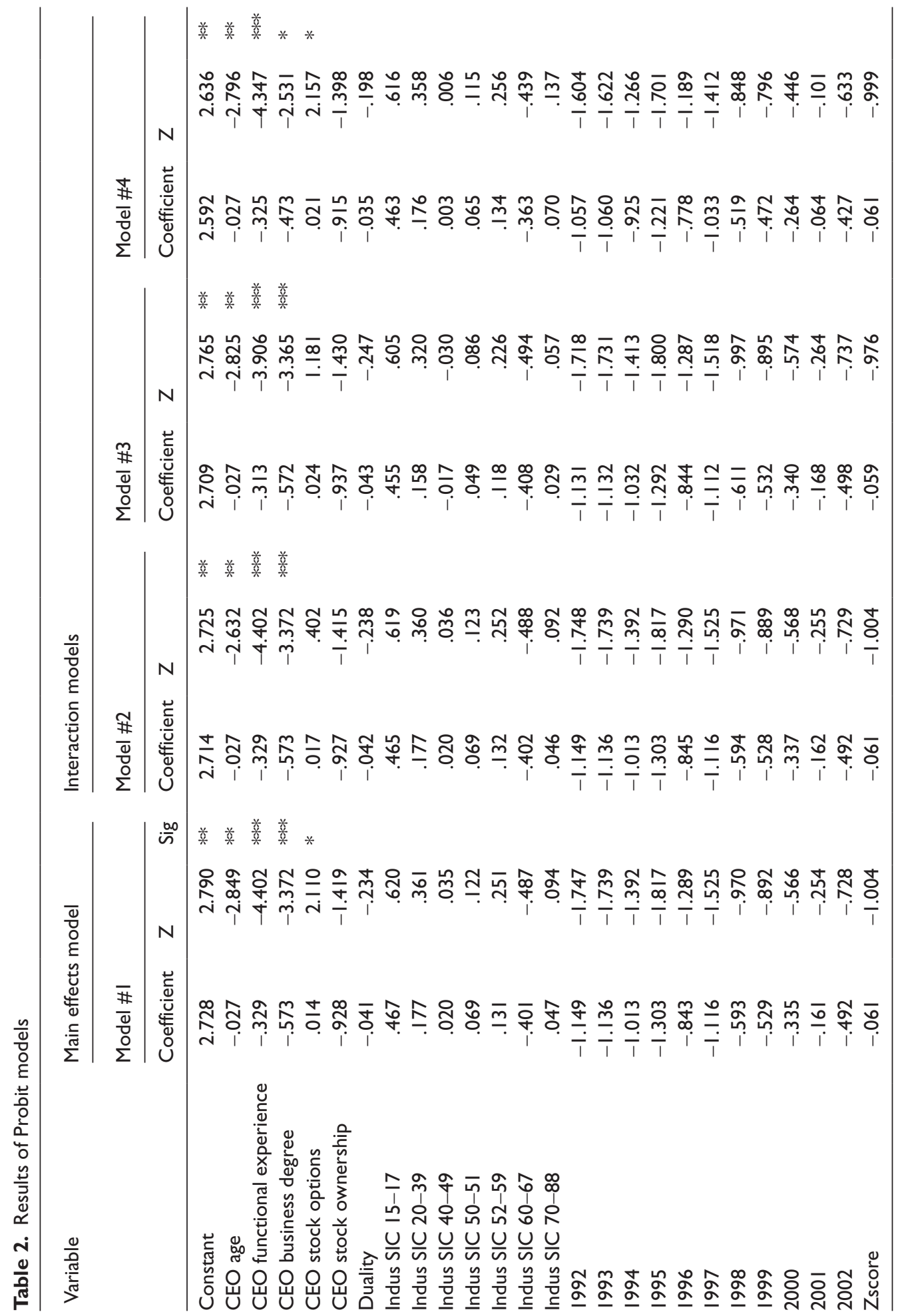




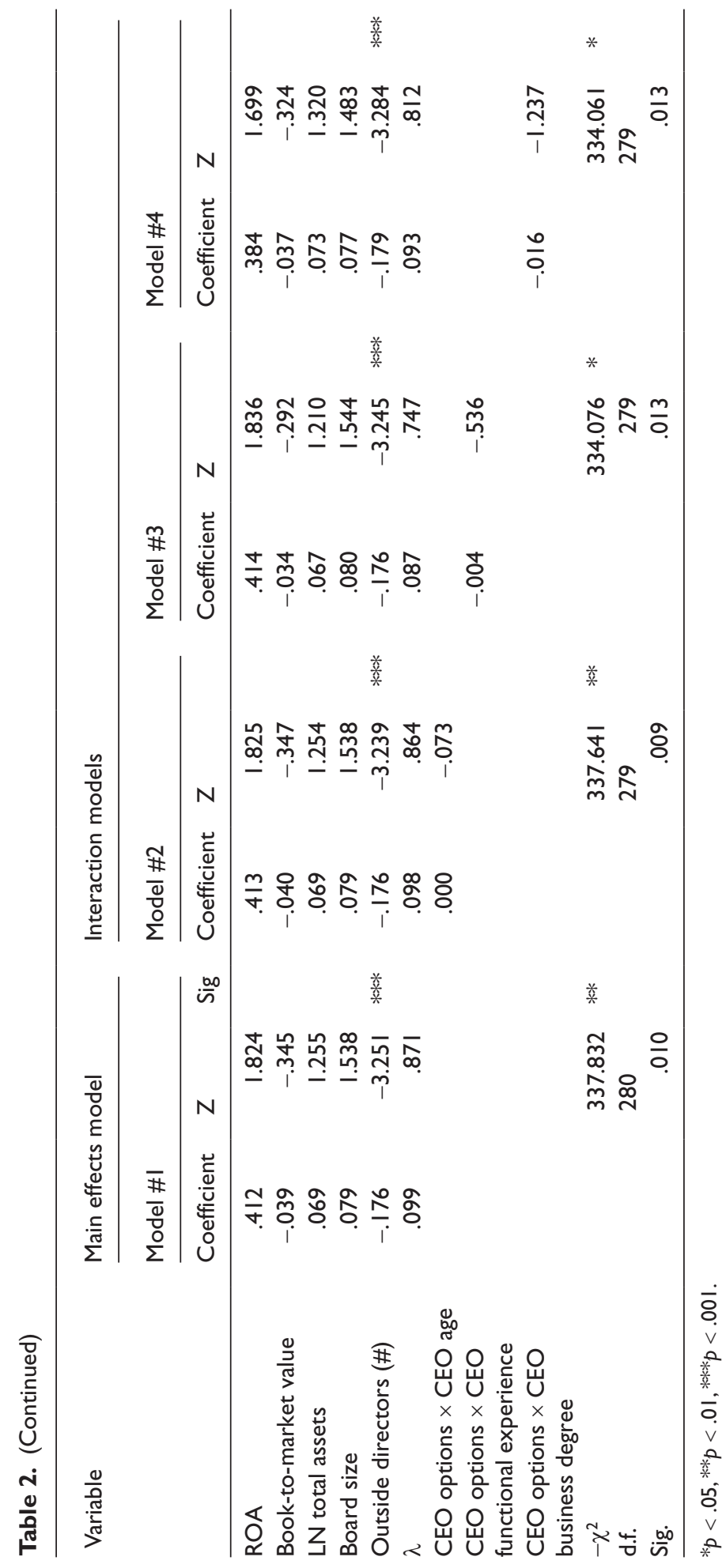


Our fourth hypothesis conjectures that the relationship between CEO demographics and the likelihood of accounting fraud will be moderated by the level of stock options. Based on Zahra et al. $(2005,2007)$ we expected to find that older, more functionally experienced CEOs and those who hold a business degree would be less influenced by high levels of stock options than would younger, less functionally experienced CEOs and those not having a business degree, and would, therefore, reduce even further the likelihood of accounting fraud. This hypothesis is not supported by our data. As will be discussed, we carried out a number of robustness tests to examine alternative explanations of the results. These robustness checks support our findings reported above.

\section{Discussion}

This research examined the relationship between key CEO demographics and accounting fraud. Responding to a call for more empirical study of the behavioral perspectives of corporate elites (Pettigrew, 1992), we develop theory from cognitive psychology and specifically from the study of rationalizations (e.g. cognitions, perceptions and interpretations) to advance upper echelon theory (Hambrick, 2007a). We utilize the fraud triangle (Cressey, 1953) and the framework of top management fraud (Zahra et al., 2007) to conceptualize our study of who is more likely to rationalize the facilitation of financial statement fraud. Our goal was to aid in understanding of executive rationalizations needed to justify unethical behavior. As suggested by Hambrick (2007a) key individual differences, measured using individual demographics (e.g. age, functional experience and business education), are effective surrogates for CEO values, cognitions, perceptions and interpretations, and may be used to predict the rationalization of financial statement fraud by the CEO. In particular, we focus on the 'individual key actor' of the firm as opposed to the management team. Understanding how and why variation in individual CEOs' demographics predicts fraudulent acts is important given the continued involvement of CEOs in financial statement fraud.

Our specific contribution is to advance the upper echelon perspective (Hambrick and Mason, 1984) by suggesting how variations in CEO demographic variables are related to cognitive interpretations and perceptions and result in the rationalization of accounting fraud. As noted, it has been accepted that demographics relate to differences in cognition and knowledge, but how these demographics relate to cognition and knowledge has not been delineated. In addition, the negative direct effect of stock options on CEO fraud is well cataloged. In this regard, we examine how stock options moderate the relationship between CEO demography and the likelihood of accounting fraud.

While we cannot directly measure the CEO's values and perceptions, nor are we able to evaluate his/her cognitions, interpretations or perceptions, we use key demographic characteristics as surrogates for executive rationalization (Hambrick, 2007a), which is impacted by differences in perceptions and interpretations (Starbuck and Mezias, 1996). We propose that cognitions, perceptions and interpretations will differ with CEO demographics. In turn, we suggest that these variations will influence the $\mathrm{CEO}$ and therefore affect $\mathrm{CEO}$ rationalization.

Our analysis was conducted using a Heckman procedure to correct for selection bias. Our regression model includes a broad set of controls suggested in the literature - industry, firm size, financial condition, time and governance. We find the relationships between the key CEO demographics of age, experience and education, and accounting fraud are negative and significant. The results of the regression model support our hypotheses 1,2 and 3: that CEOs who are younger, have had fewer in-firm functional positions prior to becoming CEO and do not have a business degree are more likely to commit accounting fraud than their older, more functionally experienced counterparts who have business degrees. Although options predict fraud, the results of our 
regression model interactions do not provide support for our fourth hypothesis that high amounts of CEO stock options moderate the relationship between CEO demographics and the likelihood of accounting fraud.

We ran several additional models (results not reported) that used different indicator variables ${ }^{2}$ for Heckman's correction and also conducted our analysis using two additional measures of CEO stock options: the Black-Scholes value and the value of the exercisable options, both as reported in the company proxy statements. In each case the results are consistent with those reported in Table 2; the coefficients for the CEO demographic variables are negative and significant and none of the interactions of CEO demographic variables with CEO stock options are statistically significant. In this respect our results are robust. In the context of rationalization, we do not find that higher levels of CEO stock options make a significant impact on the direct effects relationship of CEO demographics and accounting fraud.

In terms of practical interpretations of our results, Schwab et al. (2010) show that null-hypothesis testing has its challenges, including the difficulty to interpret and understand the results. What does it mean that the CEOs of the fraud firms were significantly younger than the CEOs of the control firms, when the average age difference is 2.3 years? There is not much that is practically useful in such a minor difference in the average age. Nevertheless, it is helpful to examine the overall age levels of the two groups, which shows that the fraud firms had more CEOs that were in their thirties or early forties and fewer CEOs that were over 60 or 65 than the control firms. For the fraud firms, 48 (30.8 percent) of the CEOs were aged 45 or younger, as compared to 29 ( 18.6 percent) of the CEOs in the control firms. In the fraud firms 25 (16.0 percent) of the CEOs had reached age 60 as opposed to 36 (23 percent) for CEOs in the control firms. Only 7 (4.4 percent) CEOs were age 65 or above in the fraud firms while 15 (9.6 percent) of the CEOs in the control had reached age 65 or higher.

Why would age directly impact the top executive's rationalization of fraud? As suggested by prior literature (see, for example, Daboub et al., 1995), younger CEOs are more risk tolerant and more vulnerable to external pressure. Conversely, older CEOs, with their higher levels of cognitive development, greater awareness and more life experiences, may not rationalize the fraud, given the perceived risks of fines, reputation and imprisonment if caught. Since our fraud firms' CEOs are, on average, further away from retirement and have not had as long to develop their reputation as an executive, we speculate that age explains to some extent the rationalization and participation in fraud as evidenced by the finding in our study that younger CEOs are more likely to engage in fraud.

The CEOs of the fraud firms held on average 1.46 in-firm functional positions prior to becoming CEO, while the CEOs of the control firms on average held nearly two (1.94) in-firm functional positions prior to becoming CEO. The breadth of in-firm experience becomes more evident when examining the data for CEOs with no functional experience in the firm. In the fraud firms, 54 (37.2 percent) of CEOs had no prior functional experience in the firm compared to 36 (23.1 percent) of the CEOs in the control firms. Why would lower in-firm functional experience directly impact the top executive's rationalization of fraud? One plausible explanation is that fraud firms may be more likely to have a CEO that was not promoted from within the company. It is not uncommon to bring in an outsider, particularly if the firm's performance is declining. Thus, a CEO may have been hired for fresh ideas or to turn the company around. This CEO may be viewed as an expert or turnaround champion, and rationalize his/her actions accordingly. Although additional research is necessary, our results imply that the breadth of in-firm functional experience is an important fraud variable. Whether career functional experience has a different or even stronger impact than in-firm experience, or the type of in-firm experience matters, is a topic for future research. 
The CEOs of the fraud firms were also less likely to have had business education. Business education, which we define as an undergraduate or graduate degree in one of the traditional business areas, such as management, accounting, finance and marketing, provides an awareness of what encompasses accepted financial reporting and ethical business practices. We theorized that CEOs with business education may acquire greater knowledge of accounting and financial skills. Although Daboub et al. (1995) theorized that business executives would be more likely to commit illegal activities, they did not empirically study the question. Our results suggest that business education reduces rationalization, as it relates to accounting fraud. For the firms in our study, CEOs with business degrees at the tertiary level are more likely to head firms that are not engaging in financial statement fraud. Further research is needed to explore the specific factors or characteristics of business school curriculums that explains these results.

Surprisingly, we found no support for our fourth hypothesis: that high CEO stock options moderate the relationship between CEO functional experience and the likelihood of accounting fraud and stock options also moderate the relationship between CEO business education and the likelihood of accounting fraud. Our results suggest that the relationship between stock options and accounting fraud is less complex than previously theorized and that the relationship between stock options and accounting fraud is direct. One leg of Cressey's (1953) fraud triangle is motivation. We have assumed that CEO stock options provide a motivation for accounting fraud and our main effects model, which includes CEO stock options as an independent variable, supports our position. CEO stock options are positively and significantly associated with accounting fraud. We interpret the lack of significance of the interactions of CEO stock options and CEO demographic variables to mean that rationalization for accounting fraud is not exacerbated just because the CEO holds a proportionally large amount of stock options. Lack of significance does not necessarily translate to lack of importance (Schwab et al., 2010). The demographic variables in our study, particularly experience and business education, are negatively associated with accounting fraud. A greater likelihood of fraud is the result of less CEO experience or no business education. High levels of CEO stock options are also associated with greater likelihood of fraud, but do not make the likelihood any greater than it already is, given the CEO demographics. Stated differently, CEO demographics do not have any significant impact on the likelihood of fraud, given that a CEO with high levels of stock options is more likely to engage in fraud. ${ }^{3}$

While the results of this study are important, there are some limitations. Our empirical results are generally supportive of our theory, though we cannot confirm that the underlying theory we develop actually explains our results. That is, we cannot confirm that the black box of rationalization of accounting fraud is what is measured by demographics. It is difficult to fully explain why demographics matter in the way they do as prior research has found. The insights that we have developed are interesting, but like most other demographic studies, we are making conjectures about CEOs' cognitions, perceptions and interpretations that influence the rationalization of accounting fraud. Future research might better advance the question of demographics, if data that are more directly measures of cognitions and rationalizations become available and accessible. Limitations relating to the empirical aspects of our research also exist. By taking our sample from firms sanctioned by the SEC, we acknowledge the potential for some bias as a result of the process the SEC uses to select firms to investigate. Using the SEC enforcement actions for our initial sample selection provides as pure a sample as is possible of firms engaging in accounting fraud and is consistent with prior research on fraud (e.g. Beasley et al., 2000; Dechow et al., 1996; Feroz et al., 1991). Our research covers a period of 13 years from 1992 to 2004, and, while we have controlled for time in our model, Kaminski et al. (2004: 26) note that 'results in changing conditions within the sample period ... can also impact the model data and the prediction period'. 
In conclusion, we began this article acknowledging the continuing problem of CEO fraud. We approach financial statement fraud from the perspective of the key influencer of the firm, focusing on CEO individual demographics as proxies for cognition, perceptions and interpretations as a way to explain why some CEOs rationalize the facilitation of accounting fraud and others do not. The results of our study contribute to Hambrick's (2007a, 2007b) upper echelons framework by suggesting how variation in CEO demography leads to variation in cognitive interpretations, which in turn impacts the likelihood of accounting fraud. While encouraged by the results of our study, we acknowledge the need for additional research to investigate further the relationships between demographics, cognitions, rationalization and accounting fraud, and interactions with previously established variables which have been linked to CEO fraud.

\section{Funding}

This research received no specific grant from any funding agency in the public, commercial, or not-for-profit sectors.

\section{Notes}

1. See Hamilton and Nickerson (2003), Bascle (2008) and Smits (2003) for detailed explanations of the Heckman procedure.

2. These other indicator variables were related to governance (dichotomous variable $=1$, if majority of board members were insiders and 0 , otherwise); firm size (large vs medium/small) and incentive compensation (existence of current stock option awards and exercisable options).

3. We also explored a variety of other governance moderation variables (duality, founder, board outsiders) as these also may affect the CEO's opportunity to engage in accounting fraud. Using Heckman's correction, we found a direct negative effect for the number of outside board members, controlling for total board members. However, the number of outside board members did not moderate the CEO demographic fraud relationship.

\section{References}

Altman, E. I. (1968) 'Financial Ratios, Discriminant Analysis and the Prediction of Corporate Bankruptcy', Journal of Finance 23(4): 589-609.

Anand, V., Blake, E. and Joshi, M. (2004) 'Business as Usual: The Acceptance and Perpetuation of Corruption in Organizations', Academy of Management Review 19(3): 9-23.

Antenucci, J., Tackett, J., Wolf, F. and Claypool, G. (2010) 'The Rationalization of Academic Dishonesty in Business Students', Journal of Business and Accounting 2(1): 77-92.

Ashford, B. E. and Anand, V. (2003) 'The Normalization of Corruption in Organizations', Research in Organizational Behavior 25: 1-52.

Aspen Institute for Social Innovation Through Business (2001) Where Will They Lead? MBA Student Attitudes About Business and Society. New York: Aspen ISIB.

Bantel, K. A. and Jackson, S. E. (1989) 'Top Management and Innovations in Banking: Does the Composition of the Top Team Make a Difference?', Strategic Management Journal 10: 107-24.

Barker, V. L. III and Mueller, G. C. (2002) 'CEO Characteristics and Firm R\&D Spending', Management Science 48(6): 782-801.

Bascle, G. (2008) 'Controlling for Endogeneity with Instrumental Variables in Strategic Management Research', Strategic Organization 6(4): 285-326.

Beasley, M. S. (1996) 'An Empirical Analysis of the Relation between the Board of Director Composition and Financial Statement Fraud', The Accounting Review 71(4): 443-65. 
Beasley, M. S., Carcello, J. V., Hermanson, D. R. and Lapides, P. D. (2000) 'Fraudulent Financial Reporting: Consideration of Industry Traits and Corporate Governance Mechanisms', Accounting Horizons 14: 441-54.

Beasley, M. S., Carcello, J. V. and Hermanson. P. D. (2001) 'Financial Reporting Fraud: Could it Happen to You?', Journal of Corporate Accounting and Finance 12(4): 3-9.

Boone, C and Hendricks, W. (2009) 'Top Management Team Diversity and Firm Performance: Moderators of Functional-Background and Locus-of-Control Diversity', Management Science 55(2): 165-80.

Brockman, P., Martin, X. and Unlu, E. (2010) 'Executive Compensation and the Maturity Structure of Corporate Debt', The Journal of Finance 65(3): 1123-61.

Brouthers, K. D., Brouthers, L. E. and Werner, S. (2000) 'Influences on Strategic Decision-Making in the Dutch Financial Services Industry', Journal of Management 26: 863-83.

Burns, N. and Kedia, S. (2008) 'Executive Option Exercises and Financial Misreporting', Journal of Banking and Finance 32(5): 845-57.

Business Week (2002) 'The Rise and Fall of Dennis Kozlowski', 24 June: 34.

Carcello, J. V. and Nagy, A. L. (2004a) ‘Audit Firm Tenure and Fraudulent Financial Reporting', Auditing 23(2): 55-69.

Carcello, J. V. and Nagy, A. L. (2004b) 'Client Size, Auditor Specialization and Fraudulent Financial Reporting', Managerial Auditing Journal 19(5): 651-68.

Chandy, P. R. (1991) 'Chief Executive Officers: Their Backgrounds and Predictions for the 90s', Business Forum 16(1):18-19.

Cheng, Q. and Farber, D. B. (2008) 'Earnings Restatements, Changes in CEO Compensation, and Firm Performance', Accounting Review 83(5): 1217-50.

Cheng, Q. and Warfield, T. D. (2005) 'Equity Incentives and Earnings Management', The Accounting Review 80: 441-76.

Child, J. (1974) 'Managerial and Organizational Factors Associated with Company Performance-Part 1', Journal of Management Studies 11: 175-89.

Clinard, M. B. and Yeager, P. C. (1980) Corporate Crime. New Brunswick, NJ: Transaction Publishers/Free Press.

COSO (1999) 'Fraudulent Financial Reporting 1987-1997, an Analysis of U.S. Public Companies', Committee of Sponsoring Organizations of the Treadway Commission.

Cressey, D. R. (1953) Other People's Money: A Study of the Social Psychology of Embezzlement. Glencove, IL: Free Press.

Daboub, A. J., Rasheed, A. M. A., Priem, R. L. and Gray, D. A. (1995) 'Top Management Team Characteristics and Corporate Illegal Activity', Academy of Management Review 20: 138-70.

Dechow, P. M., Sloan, R. G. and Sweeney, A. P. (1996) 'Causes and Consequences of Earnings Manipulations: An Analysis of Firms Subject to Enforcement Actions by the SEC', Contemporary Accounting Research 13: $1-36$.

Dechow, P. M., Richardson, S. A. and Tuna, I. (2003) 'Why are Earnings Kinky? An Examination of the Earnings Management Explanation', Review of Accounting Studies 9(2-3): 355-84.

DeFusco, R. A., Johnson, R. R. and Zorn, T. S. (1990) 'The Effect of Executive Stock Option Plans on Stockholders and Bondholders', The Journal of Finance 45(2): 617-27.

Dunn, P. (2004) 'The Impact of Insider Power on Fraudulent Financial Reporting', Journal of Management 30: 397-412.

Erickson, M., Hanlon, M. and Maydew, E. (2006) 'Is There a Link between Executive Equity Incentives and Accounting Fraud?', Journal of Accounting Research 44(1): 113-43.

Ertugrul, M. and Krishnan, K. (2010) 'Can CEO Dismissals be Proactive?', Journal of Corporate Finance 17: $134-51$. 
Ermann, M. D. and Lundman, R. J. (1987) Corporate and Governmental Deviance, 3rd edn. Oxford: Oxford University Press.

Feroz, E. H., Park, K. and Pastena, V. S. (1991) 'The Financial and Market Effects of the SEC's Accounting and Auditing Enforcement Releases', Journal of Accounting Research 29 (Supplement): 107-42.

Festinger, L. (1957) Theory of Cognitive Dissonance. Stanford, CA: Stanford University Press.

Finkelstein, S. and Hambrick D. C. (1996)) Strategic Leadership: Top Executives and Their Effects on Organizations. St Paul, MN: West Publishing Company.

Fiske, S. T. and Taylor, S. E. (1991) Social Cognition, 2nd edn. New York: McGraw-Hill.

Fong, G. T., Krantz, D. H. and Nisbett, R. E. (1986) 'The Effects of Statistical Training on Thinking About Everyday Problems', Cognitive Psychology 18(3): 253-92.

Freeman, R. E. and Gilbert, D. (1988) Corporate Strategy and the Search for Ethics. Englewood Cliffs, NJ: Prentice Hall.

Glaser, R. (1984) 'Education and Thinking', American Psychology 39: 93-104.

Gioia, D. (2002) 'Business Education's Role in the Crisis of Corporate Confidence', The Academy of Management Executive 16(3): 142-4.

Gioia, D. and Corley, K. (2002) 'Being Good versus Looking Good: Business School Rankings and the Circean Transformation from Substance to Image', Academy of Management Learning and Education 1: 107-20.

Greve, H., Palmer, D. and Pozner, P (2010) 'Organizations Gone Wild: The Causes, Processes, and Consequences of Organizational Misconduct', Academy of Management Annals 4(1): 53-107.

Grimm, C. M. and Smith, K. G. (1991) 'Management and Organizational Change: A Note on the Railroad Industry', Strategic Management Journal 12(7): 557-62.

Gross, E. (1978) 'Organizational Crime: A Theoretical Perspective', in N. Denzin (ed.) Studies in Symbolic Interaction, pp. 55-85. Greenwich, CT: JAI Press.

Gupta, A. K. (1984) 'Contingency Linkages between Strategy and General Manager Characteristics: A Conceptual Examination', The Academy of Management Review 9: 399-412.

Hall, B. J. and Murphy, K. J. (2002) 'Stock Options for Undiversified Executives', Journal of Accounting and Economics 33: 3-42.

Hambrick, D. C. (2007a) 'Upper Echelons Theory: An Update', Academy of Management Review 32: 334-43.

Hambrick, D. C. (2007b) 'The Field of Management's Devotion to Theory: Too Much of a Good Thing?', Academy of Management Journal 50(6): 1346-52.

Hambrick, D. C. and Mason, P. A. (1984) 'Upper Echelons: The Organization as a Reflection of its Top Managers', Academy of Management Review 9: 193-206.

Hamilton, B. and Nickerson, J. (2003) 'Correcting for Endogeneity in Strategic Management Research', Strategic Organization 1: 51-78.

Herrmann, P. (2002) 'The Influence of CEO Characteristics on the International Diversification of Manufacturing Firms: An Empirical Study in the United States', International Journal of Management 19: 279-89.

Hunt, S. D. and Chonko, L.B. (1984) 'Marketing and Machiavellianism', Journal of Marketing 48(3): 30-42.

Ireland, R. D., Hitt, M. A., Bettis, R. A. and De Porras, D. A. (1987) 'Strategy Formulation Processes: Differences in Perceptions of Strength and Weaknesses Indicators and Environmental Uncertainty by Managerial Level', Strategic Management Journal 8(5): 469-85.

Jensen, M. C. (2001) 'Corporate Budgeting is Broken: Let's Fix It', Harvard Business Review 79(10): 95-106. Jia, C., Ding, S., Li, Y. and Wu, Z. (2009) 'Fraud, Enforcement Action, and the Role of Corporate Governance: Evidence from China', Journal of Business Ethics 90(4): 561-76.

Jones, K. L., Krishnan, G. V. and Melendrez, K. D. (2008) 'Do Models of Discretionary Accruals Detect Actual Cases of Fraudulent and Restated Earnings? An Empirical Analysis', Contemporary Accounting Research 25(2): 499-531. 
Kaminski, K. A., Wetzel, T. S. and Guan, L. (2004) 'Can Financial Ratios Detect Fraudulent Financial Reporting?', Managerial Auditing Journal 19(1): 15-28.

Kang, J.-K. and Shivdasani, A. (1997) 'Corporate Restructuring During Performance Declines in Japan', Journal of Financial Economics 46 (1): 29-65.

Kelley, S. W., Ferrell, O. C. and Skinner, S. J. (1990) 'Ethical Behavior among Marketing Researchers: An Assessment', Journal of Business Ethics 9(8): 681-8.

Kriesberg, S. M. (1976) 'Decision Making Models and the Control of Corporate Crime', The Yale Law Journal 85: 1091-129.

Laux, C. and Laux, V. (2009) 'Board Committees, CEO Compensation, and Earnings Management', Accounting Review 84(3): 869-91.

Lee, L. (1983) 'Notes and Comments: Generalized Econometric Models with Selectivity', Econometria 51(2): 507-12.

Lehman, D. R., Lempert, R. O. and Nisbett, R. E. (1988) 'The Effects of Graduate Training on Reasoning: Formal Discipline and Thinking About Everyday-Life Events', American Psychologist 43(6): 431-42.

MacCrimmon, K. R. and Wehrung, D. A. (1990) 'Characteristics of Risk-taking Executives', Management Science 36: 422-35.

McKendall, M. A. and Wagner, J. A. III (1997) 'Motive, Opportunity, Choice, and Corporate Illegality', Organization Science 8(6): 624-47.

Markóczy, L. (1997) 'Measuring Beliefs: Accept No Substitutes', Academy of Management Journal 40(5): $1228-42$.

Merton, R. K. (1938) 'Social Structure and Anomie', American Sociological Review 3(5): 672-82.

Messick, D. M. and Bazerman, M. H. (1996) 'Ethical Leadership and the Psychology of Decision-Making', Sloan Management Review 37(2): 9-22.

Morck, R., Schleifer, A. and Vishny, R. (1990) 'Do Managerial Objectives Drive Bad Acquisitions?', Journal of Finance 45: 31-48.

New York Daily News (2009) at: www.nydailynews.com/money/2009/06/30/2009-06-30_they_too_paid_ for_fast_living.html.

New York Times (2007) at: www.nytimes.com/2007/01/04/business/04enron.html.

New York Times (2009) at: topics.nytimes.com/top/reference/timestopics/people/m/bernard_1_madoff/index. html? scp=1\&sq=Bernard\%20Madoff $\% 20$ sentenced\&st $=$ cse.

Nielson, S. (2009) 'Why do Top Management Teams Look the Way They Do? A Multilevel Exploration of the Antecedents of TMT Heterogeneity', Strategic Organization 7(4): 277-305.

Ning, Y., Davidson, W. N. and Zhong, K. (2007) 'The Variability of Board Size Determinants: An Empirical Analysis', Journal of Applied Finance 17(2): 46-61.

O’Connor, J. P. Jr, Priem, R. L., Coombs, J. E. and Gilley, K. M. (2006) 'Do CEO Stock Options Prevent or Promote Fraudulent Financial Reporting?', Academy of Management Journal 49(3): 483-500.

Palia, D. (2000) 'The Impact of Regulation on CEO Labor Markets', The RAND Journal of Economics 31(1): 165-79.

Pettigrew, A. M. (1992) ‘On Studying Management Elites', Strategic Management Journal 13(2): 163-70.

Pfeffer, J. and Fong, C. (2004) 'The Business School Business: Some Lessons from the U.S. Experience', The Journal of Management Studies 41: 1501-20.

Pfeffer, J. and Salancik, G. (1978) The External Control of Organizations. New York: Harper and Row.

Prawitt, D. F., Smith J. L. and Wood, D.A. (2009) 'Internal Audit Quality and Earnings Management', Accounting Review 84(4): 1255-80.

Price, M. and Norris, D. (2009) 'White-Collar Crime: Corporate and Securities and Commodities Fraud', The Journal of the American Academy of Psychiatry and the Law 37: 538-44.

Report of the National Commission on Fraudlent Financial Reporting (1987) at: www.coso.org/publications/ ncffr.pdf. 
Rest, J. R. and Thoma, S. J. (1985) 'Relation of Moral Judgment Development to Formal Education', Developmental Psychology 21(4): 709-14.

Reynolds, S. J. (2006) 'A Neurocognitive Model of the Ethical Decision-Making Process: Implications for Study and Practice', Journal of Applied Psychology 91(4): 737-48.

Schrand, C. M. and Zechman, S. L. (2010) 'Executive Overconfidence and the Slippery Slope to Fraud', AAA 2009 Financial Accounting and Reporting Section (FARS) Paper, Chicago Booth Research Paper No. 08-25; at: ssrn.com/abstract=1265631.

Schwab, A., Abrahamson, E., Starbuck, W. and Fidler, F. (2010) 'Perspective: Researchers Should Make Thoughtful Assessments Instead of Null-Hypothesis Significance Tests', Organization Science 22(4): 1105-20.

Searcey, D. and Yuan, L. (2005) 'Adelphia's John Rigas Gets 15 Years; Judge Gives 80-Year-Old an Effective Life Sentence; 20 Years for Son Timothy', Wall Street Journal 21 June: A3.

Serwinek, P. (1992) 'Demographic and Related Differences in Ethical Views Among Small Businesses', Journal of Business Ethics 11(7): 555-66.

Shuman, H. and Scott, J. (1989) 'Generations and Collective Memories', American Sociological Review 54(3): 359-81.

Siegel, L. (1992) Criminology, 4th edn. St Paul, MN: West Publishing Company.

Slater, D. and Dixon-Fowler, H.(2010) 'The Future of the Planet in the Hands of MBAs: An Examination of CEO MBA Education and Corporate Environmental Performance', Academy of Management Learning and Education 9(3): 429-42.

Smith, K. G., Smith, K. A., Olian, J. D., Sims, H. P. Jr, O’Bannon, D. P. and Scully, J. A. (1994) 'Top Management Team Demography and Process: The Role of Social Integration and Communication', Administrative Science Quarterly 39(3): 412-38.

Smits, J. (2003) 'Estimating the Heckman Two-Step Procedure to Control for Selection Bias with SPSS'; at: home.planet.nl/ smits.jeroen.

Starbuck, W. and Mezias, J. (1996) 'Opening Pandora's Box: Studying the Accuracy of Managers' Perceptions', Journal of Organizational Behavior 17(2): 99-117.

Stone, C. (1975) Where the Law Ends: The Social Control of Corporate Behavior. New York: Harper and Row.

Stone, E. J. (1992) 'New Executive Compensation Disclosures Proposed by the SEC', Journal of Corporate Accounting and Finance 4(1): 91-6.

Sutherland, E. H. (1949) White Collar Crime. New York: Holt, Rinehart and Winston.

Tosi, H. L., Werner, S., Katz, J. P. and Gomez-Mejia, L. R. (2000) 'How Much Does Performance Matter? A Meta-Analysis of CEO Pay Studies', Journal of Management 26(2): 301-39.

Uzun, H., Szewczyk, S. H. and Varma, R. (2004) 'Board Composition and Corporate Fraud', Financial Analysts Journal 60(3): 33-43.

Wall Street Journal (2007) at: blogs.wsj.com/law/2007/08/07/in-advance-of-prison-john-rigas-speaks-out/.

Wiersema, M. F. and Bantel, K. A. (1992) 'Top Management Team Demography and Corporate Strategic Change', Academy of Management Journal 35(1): 91-120.

Zahra, S. A., Priem, R. L. and Rasheed, A. A. (2005) 'The Antecedents and Consequences of Top Management Fraud', Journal of Management 31: 803-28.

Zahra, S. A., Priem, R. L. and Rasheed, A. A. (2007) 'Understanding the Causes and Effects of Top Management Fraud', Organizational Dynamics 36(2): 122-39.

Zhang, X., Bartol, K. M., Smith, K. G., Pfarrer, M. and Khanin, D. (2008) 'CEOs on the Edge: Earnings Manipulation and Stock-Based Incentive Misalignment', Academy of Management Journal 51(2): 241-58. 


\section{Author biographies}

Carmelita Troy, associate professor, teaches accounting and financial statement analysis at Andrews University. Her research interests are in the areas of accounting and control fraud. Her research has been published in the Journal of Business Ethics and the Journal of Business and Economics Research. Carmelita has worked in treasury and human resources in the not-for-profit sector. In 2008, 2009 and 2011 she won the School of Business Administration student-choice Outstanding Teacher of the Year award. Address: School of Business Administration, Andrews University, Chan Shun Hall, 4185 E Campus Circle Drive, Berrien Springs, Michigan 49103-0024, USA. [email: troyc@andrews.edu]

Ken G. Smith joined the University of Rhode Island in 2010 as Professor of Entrepreneurship and Strategy in the College of Business Administration. Formerly, he held the Dean's Chair and was Professor of Business Strategy at the Robert H. Smith School of Business, University of Maryland. He is well known for his research in the areas of competition, competitive advantage and strategic decision-making. His articles have been published in leading scholarly journals, such as the Academy of Management Journal, Academy of Management Review, Administrative Science Quarterly and the Strategic Management Journal. A former entrepreneur, Ken was editor of the Academy of Management Review from 1996 to 1999, and is a Fellow of the Academy of Management and the Strategic Management Society. From 2006 to 2007 he served as president of the Academy of Management. Address: College of Business Administration University of Rhode Island, Ballentine Hall, 7 Lippitt Road, Kingston, RI 02881-0802, USA. [email: kgsmith@mail.uri.edu]

Madeline A. Domino teaches intermediate accounting as an assistant professor (clinical) at Georgia State University. She is also a certified public accountant. Madeline's research interests include accounting fraud, ethics and human factors in systems development. Her research has been published in Information Management and Technology, the Journal of Computer Information Systems and the Journal of Business and Economics Research. Prior to joining academia Madeline spent over 25 years in both public accounting and in management positions at Deloitte, LTD, PricewaterhouseCoopers, LTD, Sun Microsystems and Bank of America. At Bank of America, she was a member of the senior management team and the audit committee Florida affiliate, as well as a nationwide lead in merger integration. Address: School of Accountancy, Georgia State University, J. Mack Robinson College of Business, 35 Broad Street, Suite 529, PO Box 3989, Atlanta, Georgia 30303-3989, USA. [email: mdomino@gsu.edu] 